\title{
Clubmoss effects on plant water status and standing crop
}

\author{
TYLER J. COLBERG AND J.T. ROMO
}

Authors are former graduate Research Assistant and Professor, Dept. of Plant Sciences, Univ. of Saskatchewan, 51 Campus Drive, Saskatoon, Sask. S7N 5A8. Funding for this research was provided by a research grant to JTR from the Saskatchewan Agriculture Development Fund (Project-9600054).

Abstract

Clubmoss (Selaginella densa Rydb.), a low growing, vascular cryptogam forms carpet-like mats that cover up to $80 \%$ of the ground in the Northern Mixed Prairie. Many range managers believe clubmoss competes with grasses for water or intercepts precipitation and negatively affects plant water relations and productivity. The objective of these studies was to test the hypothesis that precipitation has greater effects on leaf xylem water potentials (Leaf ${ }_{\mathrm{xwp}}$ ) and plant productivity than clubmoss. Studies examined the effects of clubmoss on Leaf ${ }_{x w p}$ of Junegrass (Koeleria cristata Pers.) and blue grama (Bouteloua gracilis [HBK.] Lag.), and productivity of forbs and graminoids by: 1) irrigating or reducing precipitation relative to natural precipitation; 2) removing clubmoss relative to clubmoss present, and; 3) irrigating with 0.0 to $25 \mathrm{~mm}$ of water when clubmoss was present or removed. Leaf $f_{\mathrm{xwp}}$ of Junegrass and blue grama were unaffected by clubmoss through the growing season $(P=0.33)$, but Leaf $_{\text {xwp }}$ were lowest $(P \leq 0.05)$ when precipitation was reduced relative to the control and when irrigating. Standing crop of forbs was similar in the control and clubmoss removal treatment $(P=0.22)$ and among precipitation treatments $(P=$ 0.13), averaging $28 \mathrm{~g} \mathrm{~m}^{-2}(\mathrm{SE}=2.2)$. Graminoid standing crop was unaffected by clubmoss $(P=0.35)$ and was greatest $(P=$ 0.02) when irrigated $\left(74 \mathrm{~g} \mathrm{~m}^{-2}\right)$, intermediate in the control $(53 \mathrm{~g}$ $\left.\mathrm{m}^{-2}\right)$, and least $\left(36 \mathrm{~g} \mathrm{~m}^{-2}\right)$ with reduced precipitation $(\mathrm{SE}=8.7)$. Clubmoss did not affect $(P=0.70)$ total standing crop; total standing crop declined from $102 \mathrm{~g} \mathrm{~m}^{-2}$ when irrigated to $76 \mathrm{~g} \mathrm{~m}^{-2}$ in the control, and $69 \mathrm{~g} \mathrm{~m}^{-2}(\mathrm{SE}=9.0)$ with reduced precipitation. Clubmoss had no influence $(P=0.06)$ on Leaf ${ }_{x w p}$ when irrigated with 0 to $25 \mathrm{~mm}$ of water. The decline in Leaf ${ }_{x w p}$ from 1 to 7 days after irrigation was the product of the interacting effects of the amount of water applied and days after irrigation $(P=0.03)$. More than $10 \mathrm{~mm}$ of irrigation water were required to impart a

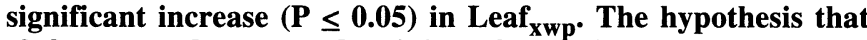
clubmoss reduces productivity of associated plants in the Northern Mixed Prairie by increasing water stress is rejected. Similarly clubmoss does not reduce plant water stress or increase production. Precipitation amounts overshadow any effects clubmoss has on Leaf ${ }_{x w p}$ and plant production. Range managers in the Northern Mixed Prairie may want to consider maximizing the effectiveness of precipitation in this water-limited environment instead of focusing on reducing or attempting to eliminate clubmoss.

Thanks are extended to Peter Gonnet for allowing studies to be conducted on the Prairie Farm Rehabilitation Administration's Rudy-Rosedale Community Pasture, and to Raelynne Colberg, Vicki Jay and Garth Wruck for assistance in many ways. We also thank Dave Junor for assisting with data collection and providing input to this project.

Manuscript accepted 30 Oct. 02.

\section{Resumen}

“Clubmoss" (Selaginella densa Rydb.) Es una planta criptógama vascular de bajo crecimiento que forma manchones de plantas semejantes a una alfombra que cubren hasta el $80 \%$ del suelo de las Praderas Mixtas del Norte. Muchos manejadores de pastizales creen que el "Clubmoss" compite con los zacates por agua o intercepta la precipitación y afecta negativamente las relaciones hídricas y productividad de los zacates. El objetivo de estos estudios fue probar la hipótesis de que la precipitación tiene mayores efectos en los potenciales hídricos del xilema de la hoja $\left(\mathrm{Hoja}_{\mathbf{x w p}}\right)$ y la productividad de la planta que el "Clubmoss". Los estudios examinaron los efectos del "Clubmoss" en el Hojaxwp de los zacates "Junegrass" (Koeleria cristata Pers.) y "Blue grama" (Bouteloua gracilis [HBK.] Lag.) y la productividad de hierbas y graminoides mediante: 1) irrigación o reduciendo la precipitación en relación a la precipitación normal; 2) removiendo el "Clubmoss" en relación al presencia del "Clubmoss" y 3) irrigando de 0.0 a $25 \mathrm{~mm}$ de agua cuando el "Clubmoss" estaba presente o ausente por remoción. A lo largo de la estación de crecimiento el Hoja ${ }_{x w p}$ del "Junegrass" y el "Blue grama" no fue afectado por la presencia del el "Clubmoss" $(P=\mathbf{0 . 3 3})$, pero los Hojaxwp fueron los mas bajos $(P \leq 0.05)$ cuando la precipitación se redujo en relación al control y cuando fueron irrigados. La biomasa en pie de las hierbas fue similar en los tratamientos control y con remoción de "Clubmoss" $(P=0.22)$ y entre tratamientos de precipitación ( $P$ $=0.13)$, promediando $28 \mathrm{~g} \mathrm{~m}^{-2}(\mathrm{ES}=2.2)$. La biomasa en pie de las graminoides no fue afectada por el "Clubmoss" $(P=0.35)$ y fue mayor $(P=0.02)$ cuando se aplico riego $\left(74 \mathrm{~g}^{-2}\right)$, intermedia en el control $\left(53 \mathrm{~g} \mathrm{~g}^{-2}\right)$ y la mas baja $\left(36 \mathrm{~g} \mathrm{~m}^{-2}\right)$ con la precipitación reducida $(\mathrm{ES}=8.7)$. El "Clubmoss" no afecto la biomasa total en pie $(P=0.70)$, la biomasa total en pie disminuyo de $102 \mathrm{~g} \mathrm{~m}^{-2}$ con irrigación a $76 \mathrm{~g} \mathrm{~m}^{-2}$ en el control y $69 \mathrm{~g} \mathrm{~m}^{-2}(\mathrm{ES}=9.0)$ con precipitación reducida. El "Clubmoss" no tuvo influencia $(P=0.06)$ en el Hoja ${ }_{x w p}$ cuando se aplico riego de 0 a $25 \mathrm{~mm}$. La disminución del Hoja ${ }_{\mathrm{xwp}}$ del día 1 al 7 después del riego fue producto de los efectos interactuantes de la cantidad de agua aplicada y los días después del riego $(P=0.03)$. Mas de $10 \mathrm{~mm}$ de agua irrigada fueron requeridos para producir un aumento significativo $(P \leq$ 0.05) en el Hoja $a_{x w p}$. Se rechazó la hipótesis de que el "Clubmoss" reduce la productividad de las plantas asociadas en las Praderas Mixtas del Norte al aumentar el estrés hídrico. Igualmente, el "Clubmoss" no reduce el estrés hídrico de las plantas o incrementa la producción. Las cantidades de precipitación sobreponen cualquier efecto que el "Clubmoss" tiene sobre el Hoja $a_{x w p} y$ la producción de planta. Los manejadores de pastizales del las Praderas Mixtas del Norte pueden querer considerar el maximizar la efectividad de la precipitación en este ambiente de precipitación limitada en lugar de enfocarse en reducir o intentar eliminar el "Clubmoss". 
Key Words: Bouteloua gracilis, cryptogams, Koeleria cristata, leaf xylem water potentials, microphytic crust, Northern Mixed Prairie, Selaginella densa

Clubmoss (Selaginella densa Rydb.), a low growing (5-20 mm), non-flowering, and vascular cryptogam grows in carpetlike mats that provide up to $80 \%$ ground cover in many plant communities in the Northern Mixed Prairie (Coupland 1950, Heady 1952, Van Dyne and Vogel 1967, Dolan and Taylor 1972). Low water-use requirements enable clubmoss to grow in areas where precipitation is insufficient for sustaining extensive cover of forbs and graminoids (Webster and Steeves 1964). Clubmoss grows over a wide range of sites with low water availability (Van Dyne and Vogel 1967) and in plant communities disturbed by excessive grazing or severe drought (Clarke et al. 1943, Heady 1952). This diminutive perennial generally increases with grazing (Campbell et al. 1962, Smoliak 1965, Van Dyne and Vogel 1967, Smoliak et al. 1972, Abouguendia 1990), but it can decrease when grazing and trampling are intense (Coupland 1950, Van Dyne and Vogel 1967).

The fine roots of clubmoss form an extensive network 2 to $5 \mathrm{~cm}$ below the soil surface (Coupland and Johnson 1964). Majorowicz (1963) concluded that clubmoss competes with grasses by absorbing water like a "sponge". Clubmoss may also reduce water availability by intercepting precipitation, with greatest water losses occurring after small precipitation events (Couturier and Ripley 1973). Extensive cover and the dense rooting of clubmoss have led some people to assume that this plant competes with grasses and negatively affects plant water relations and thus productivity, particularly during drought and in environments dominated by small precipitation events (Dolan 1966, Wagner 1966, Taylor 1967, Dolan and Taylor 1972). On the other hand, cover afforded by clubmoss may reduce runoff and erosion, modify soil temperatures, and increase soil organic matter, water infiltration, effectiveness of precipitation, and water availability (Van Dyne and Vogel 1967, Dolan and Taylor 1972, Naeth et al. 1991a, Shay et al. 2000), which may lead to increased plant production.

The objectives of our studies were to determine if clubmoss influences water relations of grasses and plant productivity. We tested the hypothesis that precipitation has greater affects on plant water relations as indicated by leaf xylem water potentials $\left(\right.$ Leaf $\left._{\mathrm{xwp}}\right)$ and plant productivity than clubmoss. Studies were designed to contrast the effects on Leaf $\mathrm{xwp}_{\mathrm{xp}}$ and productivity by: 1) supplementing precipitation through irrigation or reducing precipitation relative to natural precipitation; 2) removing clubmoss relative to clubmoss present; 3 ) observing the interactions between 1 and 2 above, and; 4) measuring Leaf $_{\mathrm{xwp}}$ following irrigation with 0 to 25 $\mathrm{mm}$ of water.

\section{Material and Methods}

\section{Study Site Descriptions}

Research was conducted at 2 sites, Dundurn and Rudy, about $60 \mathrm{~km}$ south of Saskatoon, Saskatchewan in the Dundurn Sandhills $\left(51^{\circ} 31^{\prime} \mathrm{N}, 106^{\circ} 48^{\prime} \mathrm{W}\right.$; $525 \mathrm{~m}$ elevation) during the summers of 1997 and 1998. The Dundurn Sandhills formed along the south shore of glacial lake Saskatchewan 11,000 to 14,000 years ago (Christiansen 1979). Both study sites are Sandy Range
Sites (Abouguendia 1990) with Dark Brown Chernozemic soils of the Asquith association (Ellis et al. 1970). This soil developed on sandy, glacio-fluvial and lacustrine deposits, and is moderately coarse-textured. Hulett et al. (1966) described the plant communities in this area.

Annual precipitation ranges from 313 to $423 \mathrm{~mm}$ in the Northern Mixed Prairie of southern Saskatchewan and Alberta (Table 1). From April through September about 41 to $58 \%$ of the daily precipitation events are $\leq 2.5 \mathrm{~mm}$, and about 84 to $89 \%$ of daily precipitation events are $\leq 10 \mathrm{~mm}$. Annual precipitation at the study sites averages $315 \mathrm{~mm}$, with about $65 \%$ received from late-April through September (Environment Canada 1982). Most of this precipitation is received in May and June.

Precipitation totaled $187 \mathrm{~mm}$ from September 1996 through April 1997, 10 $\mathrm{mm}$ in May, $92 \mathrm{~mm}$ in June, $7 \mathrm{~mm}$ in July, and $78 \mathrm{~mm}$ in August 1997 for a total of $374 \mathrm{~mm}$ (Table 2). About $63 \mathrm{~mm}$ of precipitation were received from September 1997 through April 1998, with an additional $13 \mathrm{~mm}$ received in May, $67 \mathrm{~mm}$ in June, $69 \mathrm{~mm}$ in July, and $30 \mathrm{~mm}$ in August 1998 for a total of $242 \mathrm{~mm}$. Temperatures in this area range from an average of $-17^{\circ} \mathrm{C}$ in January to $19^{\circ} \mathrm{C}$ in July (Environment Canada 1982). The first month of the year with mean monthly temperatures above $0^{\circ} \mathrm{C}$ was April in 1997 and 1998; July and August were the warmest months in both years.

Cattle-proof exclosures, about 2 ha in size, were established immediately before applying treatments at each site. Although detailed records of use are not available, cattle had grazed the study sites in late summer to early autumn for many years before our studies were initiated. Annual

Table 1. Annual precipitation and probabilities of daily precipitation events of different sizes during April-September in the Northern Mixed Prairie at 7 locations in Saskatchewan and 4 locations in Alberta. Data are for the period of 1966-1995 (Environment Canada). Column totals may not equal exactly $100 \%$ because of rounding errors.

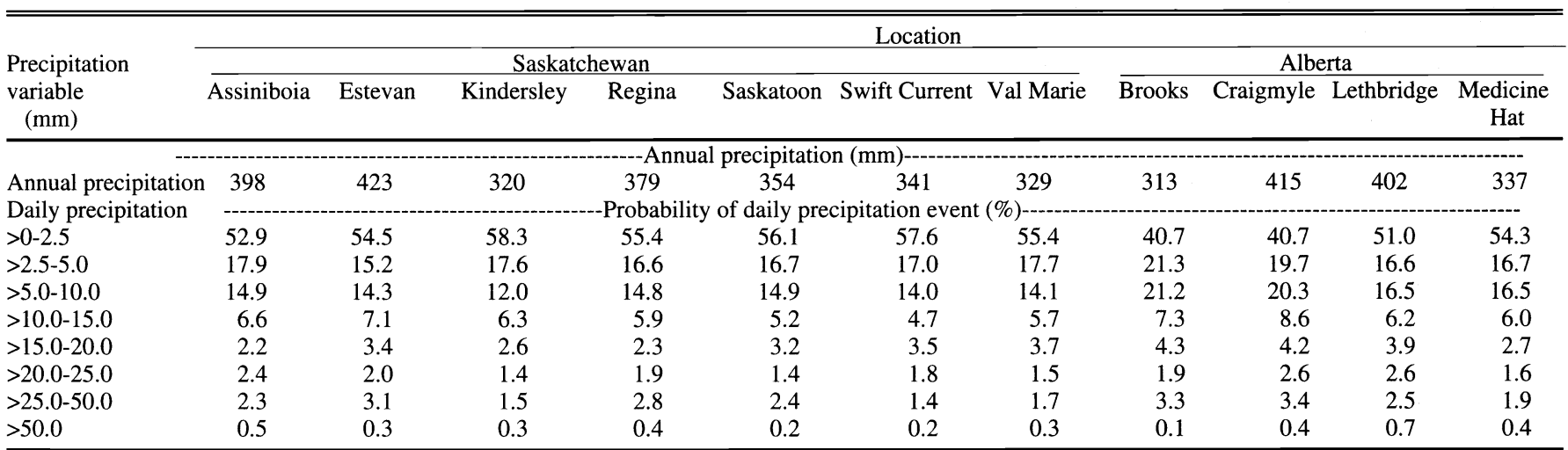


Table 2. Precipitation $(\mathrm{mm})$ received at Dundurn and Rudy during the study from May through August 1997 and 1998.

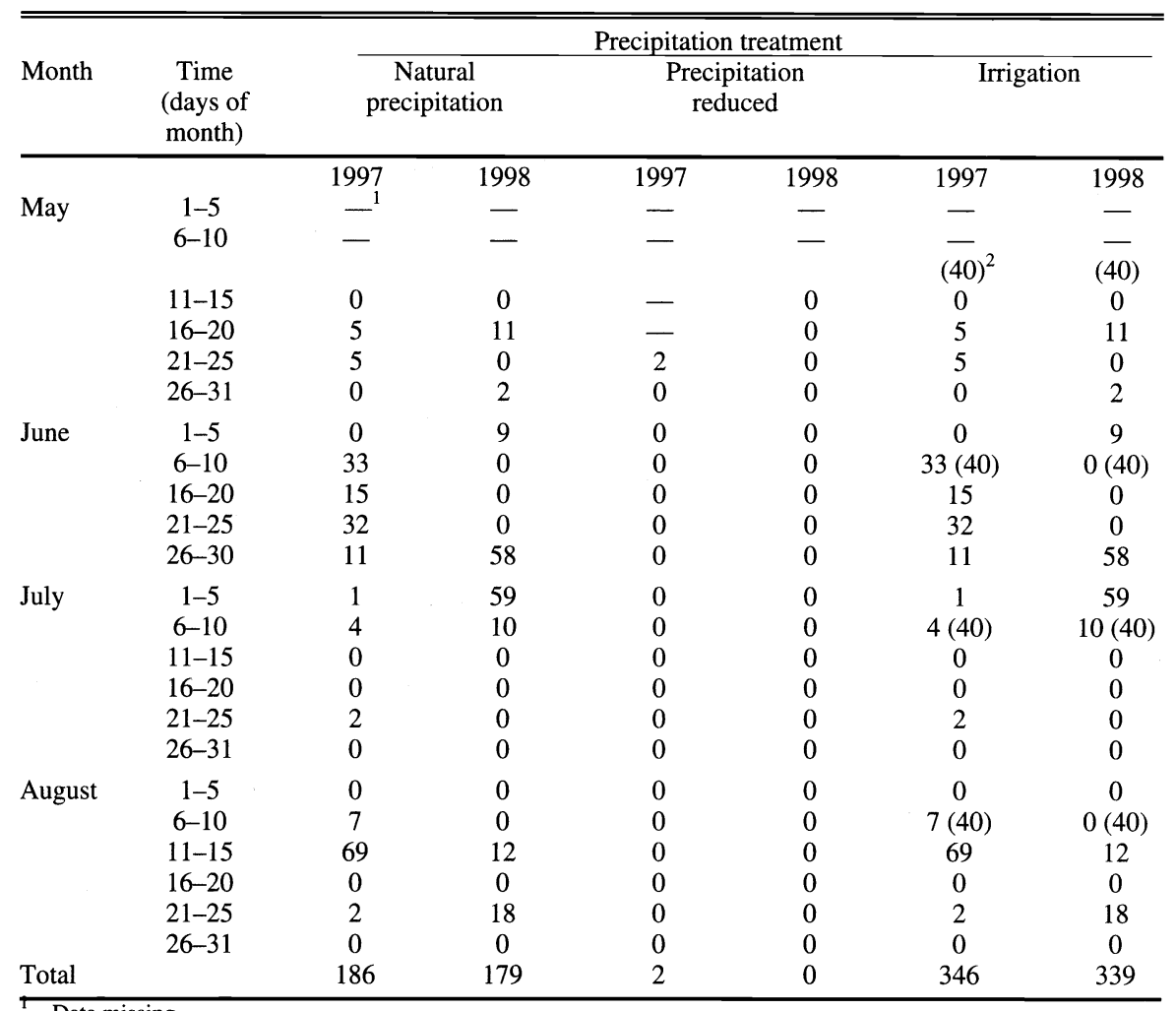

2 -Data missing.
$40 \mathrm{~mm}$ of additional water were supplied by irrigation during this period.

utilization of graminoids was estimated at 70 to $80 \%$ (Romo, pers. observ.). Range condition (Abouguendia 1990) was poor (range condition score $=20 \%$ ) at Dundurn and fair (range condition score $=30 \%$ ) at Rudy.

\section{Experiment 1-Effects of precipita- tion and clubmoss on Leaf xwp $_{\text {and }}$ standing crop}

Two clubmoss treatments, the control and clubmoss removed, were factorially applied in combination with 3 precipitation treatments including natural precipitation, monthly precipitation augmented by irrigation with a single application of 40 $\mathrm{mm}$ of water, and precipitation reduced with rainout shelters. These treatments were intended to create a gradient of pre- cipitation to determine if clubmoss or precipitation had greater effects on plant water status. The experimental design was a randomized-complete-block with 4 replications. Clubmoss and precipitation treatments were applied to 3 - by 3 -m plots with 2-m buffer zones between plots. All measurements were restricted to a 2 - by 2 $\mathrm{m}$ area centered in each plot.

Plots were established at Dundurn in 1997, and a second set of plots was established in 1998 at Rudy, about $2 \mathrm{~km}$ away. Clubmoss treatments were applied once in April 1997 at Dundurn and once in April 1998 at Rudy; cool-season plants were initiating growth at these times. A stifftoothed garden rake was used to uproot and remove clubmoss. In some areas a small, 3-pronged, hand-held weeding tool was used to remove small patches of clubmoss without disturbing other plants. Standing crop of clubmoss from one, 50- by $50-\mathrm{cm}$ quadrat in each clubmoss removal plot was placed in paper bags, dried at $80^{\circ}$ $\mathrm{C}$ for 48 hours, and weighed. The total standing crop of clubmoss removed averaged $257 \mathrm{~g} \mathrm{~m}^{-2}(\mathrm{SE}=34)$ at Dundurn and $152 \mathrm{~g} \mathrm{~m}^{-2}(\mathrm{SE}=18)$ at Rudy. No disturbance was applied to control plots.

Basal cover of clubmoss and the amount of bare soil were determined in each 3- by 3-m plot in May 1997 at Dundurn and in May 1998 at Rudy using a point-frame (Coupland 1950). One hundred points were recorded in each plot for a total of 400 points per treatment at each site. In mid-July 1997 and 1998, canopy cover of forbs and graminoids in one $20-$ by $50-\mathrm{cm}$ quadrat was estimated in each plot and converted to midpoints of cover (Daubenmire 1959). Clubmoss in the control plots covered about $79 \%$ of the soil surface at Dundurn and $68 \%$ at Rudy (Table 3). Basal cover was greater for dead than live clubmoss, and bare soil was negligible at both sites. Clubmoss was reduced $90 \%$, and bare soil increased 14to 33-fold with clubmoss removal. Forb cover at Dundurn was twice that at Rudy, but cover of graminoids was similar. Junegrass (Koeleria cristata Pers.), blue grama (Bouteloua gracilis [HBK.] Lag.), and needle-and-thread (Stipa comata Trin. \& Rupr.) dominated the study sites; common dicots included fringed sagebrush (Artemisia frigida Willd.), late yellow locoweed (Oxytropis campestris L.), hairy golden aster (Chrysopsis villosa (Pursh) Nutt.), low goldenrod (Solidago missouriensis Nutt.), and moss phlox (Phlox hoodii Richardson).

Clubmoss treatments were factorially combined with natural precipitation, precipitation increased by irrigation, and reduced precipitation. Plots receiving natural precipitation were considered controls for the precipitation treatments. Irrigated plots simulated above-average precipitation, whereas reduced precipitation was

Table 3. Average basal cover of live and dead clubmoss, percentage of bare soil, and canopy cover of forbs and graminoids within clubmoss treatments at Dundurn and Rudy study sites.

\begin{tabular}{|c|c|c|c|c|c|c|c|c|c|c|}
\hline \multirow[b]{4}{*}{$\begin{array}{l}\text { Clubmoss } \\
\text { treatment }\end{array}$} & \multicolumn{5}{|c|}{ Dundurn } & \multicolumn{5}{|c|}{ Rudy } \\
\hline & \multirow{2}{*}{\multicolumn{2}{|c|}{$\begin{array}{c}\text { Basal cover } \\
\text { Clubmoss }\end{array}$}} & \multirow{3}{*}{$\begin{array}{r}\text { Bare } \\
\text { soil }\end{array}$} & \multirow{2}{*}{\multicolumn{2}{|c|}{ Canopy cover }} & \multicolumn{2}{|c|}{ Basal cover } & \multirow{3}{*}{$\begin{array}{r}\text { Bare } \\
\text { soil }\end{array}$} & \multirow{2}{*}{\multicolumn{2}{|c|}{ Canopy cover }} \\
\hline & & & & & & & & & & \\
\hline & Live & Dead & & Forbs & Graminoids & Live & Dead & & Forbs & Graminoids \\
\hline & & & & & & & & & & \\
\hline Control & 36 & 43 & 4 & 14 & 27 & 30 & 34 & 1 & 7 & 24 \\
\hline Removed & 3 & 7 & 55 & 10 & 17 & 6 & 3 & 33 & 8 & 19 \\
\hline
\end{tabular}


intended to intensify seasonal drought. On irrigated plots, natural precipitation was supplemented with water applications of $40 \mathrm{~mm}$ in mid-May, mid-June, mid-July, and mid-August at Dundurn in 1997 and both sites in 1998 for a total increase of $160 \mathrm{~mm}$ over natural precipitation (Table $2)$. This additional water is about $75 \%$ greater than the long-term mean precipitation received from April through August in this area (Environment Canada 1982). The probability of daily precipitation events of $40 \mathrm{~mm}$ or more is about 1.1 to $2.3 \%$ in the Northern Mixed Prairie of Saskatchewan and Alberta. Plots were irrigated with well water applied to the 3- by $3-\mathrm{m}$ plots at a rate of about 45 liter $\mathrm{min}^{-1}$. The amount and rate of irrigation was controlled using a gas-powered pump and a hose with an adjustable nozzle. Irrigation was stopped periodically throughout the application if necessary to prevent runoff.

For the reduced precipitation treatment, rainout shelters were designed to permit plant growth, but limit the amount of precipitation reaching the plots, thus accentuating summer water deficits. Rainout shelters were constructed by building a 3- $x$ 3$\mathrm{m}$ frame using boards that were 3-m long, $5-\mathrm{cm}$ wide and $10-\mathrm{cm}$ high. Two additional boards of the same size were placed through the center of each shelter for support. Heavy-duty greenhouse plastic was stretched over the frame and secured. Details of the rainout shelter design are provided by Colberg (2000). Rainout shelters were positioned about 1.0-1.2 m above the plots by fastening them to posts in each corner of the 3- by 3-m plots. Water from rain was allowed to run off the shelters into the buffer areas between plots. Rainout shelters were established on 22 April 1997 at Dundurn and taken down in mid-October 1997. In 1998, the rainout shelters were established on 3 April at Dundurn and on 10 April at Rudy.

Rain gauges (Scientific Sales Inc., Model 6300) were placed in the center of plots under the rainout shelters and control treatments. Rain received was recorded every 1 to 5 days. Across the 3 site-years of study, $2 \mathrm{~mm}$ of precipitation were recorded in rain gauges under rainout shelters (Table 2). In addition some rain was blown under the rainout shelters during intense storms, but was not captured by rain gauges.

In 1997 Leaf $_{\text {xwp }}$ were measured on 9 and 20 May, 9 and 26 June, 8 and 26 July, and 5 and 21 August at Dundurn, and in 1998 Leaf $_{\text {xwp }}$ were determined on 7 and 21 May, 11 and 25 June, 9 and 28 July, and 7 and 18 August at both study sites.
Leaf $_{\text {xwp }}$ were measured between 1100 and 1400 hours using a pressure chamber (Ritchie and Hinckley 1975). In May and June, the uppermost fully expanded leaf on a Junegrass tiller in each plot was selected whereas 1 blue grama tiller from each plot was chosen for measurement in July and August. Leaves of Junegrass were excised 3 to $4 \mathrm{~mm}$ above the collar; blue grama tillers with 2- to 4-fully emerged leaves were cut 3 to $4 \mathrm{~mm}$ above ground level. Leaf ${ }_{x w p}$ were determined immediately after excision, and measurements were completed on a block-by-block basis to minimize temporal differences among treatments. Junegrass and blue grama were chosen for measurements of Leaf ${ }_{x w p}$ to allow determinations through the growing season. Junegrass, a $\mathrm{C}_{3}$ species, grows in May and June while blue grama, a $\mathrm{C}_{4}$ grass, grows in July and August.

Peak standing crop was determined at Dundurn in early August 1997 and in late July 1998 at both sites. One quadrat (50 by $50 \mathrm{~cm}$ ) was randomly located within the 2by $2-\mathrm{m}$ sample area of each plot, and current growing season phytomass was clipped at ground level, sorted by species, and placed in paper bags. Standing dead material from previous growing seasons was considered litter and excluded from estimates. Samples were dried at $80^{\circ} \mathrm{C}$ for 48 hours and weighed.

\section{Experiment 2-Simulated Precipitation Events and Clubmoss Effects on Leaf}

This study was designed to determine the effects of clubmoss and varying amounts of simulated rainfall events on

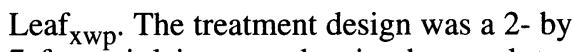
7 -factorial in a randomized-completeblock with 4 replications. The experiment was repeated 7 times including 4-11 May, 8-15 June, and 13-20 July 1997 at Dundurn, and 4-11 May, 8-15 June, 13-20 July, and 10-17 August 1998 at Rudy. New plots were established each time the experiment was repeated.

Clubmoss treatments included control and clubmoss removal as described above. Five to 10 days before conducting the experiment, clubmoss was removed from randomly assigned plots measuring 85 - by $85-\mathrm{cm}$ in size. An undisturbed, $50-\mathrm{cm}$ buffer zone was left between plots. After clubmoss was removed, a 5- by 5-m rainout shelter was placed over each treatment replication and left in place through the duration of the study. Design of the rainout shelters was the same as described earlier.

Precipitation events of various magnitudes were simulated by irrigation with a single water application of $0,2.5,5,10$, 15,20 , or $25 \mathrm{~mm}$. These water amounts were selected because of the range of size and frequency of naturally occurring precipitation events in southern Saskatchewan and Alberta (Table 1). Leaf ${ }_{\text {xwp }}$ were determined for Junegrass in May and June and for blue grama in July and August. Leaf $_{\text {xwp }}$ of Junegrass or blue grama were measured before irrigation (Day 0) using methods described earlier. The appropriate water amount for each treatment was then measured and applied to plots using garden watering cans between 1100 and 1700 hours. Leaf ${ }_{\text {xwp }}$ of Junegrass or blue grama near the center of the plots were measured $1,2,4$, and 7 days after irrigation.

\section{Data analysis}

In Experiment 1, data from the 3 siteyears of study on clubmoss and precipitation effects on Leaf xwp $_{\text {pere averaged for }}$ each replication of each treatment and date combination, and analyzed with repeated measures analysis of variance for a randomized-complete-block-design (Steel and Torrie 1980). Linear contrasts of mean Leaf $_{x w p}$ were then used to compare precipitation effects through time (Petersen 1985). Data for total standing crop and that of forbs and graminoids were analyzed with a factorial analysis of variance for a randomized-complete-block-design (Petersen 1985).

Data from all 7 repetitions of Experiment 2 were averaged for analyses. Leaf ${ }_{x w p}$ before irrigation (Day 0) were analyzed with a factorial analysis of variance (amount of water and clubmoss treatment) for a randomized-complete-block-design (Petersen 1985). Data of Leaf ${ }_{x w p}$ after irrigation were analyzed with repeated measures analysis of variance (Steel and Torrie 1980). Linear contrasts of mean Leaf $f_{x w p}$ were used to compare responses through time between control and each irrigation amount (Petersen 1985). In both experiments statistical significance was assumed at $\mathrm{P} \leq 0.05$.

\section{Results}

\section{Experiment 1}

During the course of the growing season, Leaf ${ }_{\mathrm{xwp}}$ were influenced by the interacting effects of precipitation treatment and date $(\mathrm{P}<0.01)$, but not by clubmoss $(P=0.33)$. Clear differences in Leaf ${ }_{x w p}$ were not apparent among precipitation treatments until July and August when Leaf $_{x w p}$ were lowest in the reduced precipitation treatment (Table 4). Contrasts of 
Table 4. Average Leaf ${ }_{x w p}$ for Junegrass and blue grama from May through August in control, plots in which precipitation was reduced, and irrigated plots. Leaf ${ }_{x w p}$ were determined for Junegrass in May and June and for blue grama in July and August.

\begin{tabular}{lccc}
\hline & \multicolumn{3}{c}{ Precipitation treatment } \\
\cline { 2 - 4 } $\begin{array}{l}\text { Date of } \\
\text { determination }\end{array}$ & Control & Reduced & Irrigated \\
\hline & & & \\
\hline Early May & -1.7 & -1.9 & -1.8 \\
Late May & -1.8 & -1.7 & -1.6 \\
Early Jun. & -3.0 & -2.8 & -3.0 \\
Late Jun & -1.5 & -1.8 & -1.4 \\
Early Jul. & -1.3 & -1.8 & -1.1 \\
Late Jul. & -1.7 & -2.4 & -1.4 \\
Early Aug. & -4.6 & -5.2 & -4.6 \\
Late Aug. & -1.3 & -3.7 & -1.4 \\
Standard error & & 0.35 & \\
(precipitation x Date) & & \\
\hline
\end{tabular}

means through time indicated that Leaf ${ }_{x w p}$ were lower when precipitation was reduced than in control $(\mathrm{P}<0.01)$ and the irrigation treatment $(\mathrm{P}<0.01)$; however, Leaf $_{\text {xwp }}$ were similar $(P=0.46)$ through time in the control and when irrigated.

Total standing crop $\left(83 \mathrm{~g} \mathrm{~m}^{-2}, \mathrm{SE}=5.6\right.$, $\mathrm{P}=0.70)$ and standing crop of forbs (28 $\mathrm{g}$ $\mathrm{m}^{-2}, \mathrm{SE}=2.2, \mathrm{P}=0.22$ ) and graminoids $\left(55 \mathrm{~g} \mathrm{~m}^{-2}, \mathrm{SE}=5.7, \mathrm{P}=0.35\right)$ were similar in control and the clubmoss removal treatment. Precipitation had no effect on standing crop of forbs $\left(28 \mathrm{~g} \mathrm{~m}^{-2}, \mathrm{SE}=2.2, \mathrm{P}=\right.$ $0.13)$, but graminoid $(P=0.02)$ and total standing crop $(\mathrm{P}=0.05)$ increased with precipitation. Graminoid standing crop was greatest when irrigated $\left(74 \mathrm{~g} \mathrm{~m}^{-2}\right)$, intermediate in control $\left(53 \mathrm{~g} \mathrm{~m}^{-2}\right)$, and least $\left(36 \mathrm{~g} \mathrm{~m}^{-2}\right)$ in reduced precipitation $(\mathrm{SE}=8.7)$. Likewise, total standing crop ranged from $102 \mathrm{~g} \mathrm{~m}^{-2}$ when irrigated to $76 \mathrm{~g} \mathrm{~m}^{-2}$ in the control and $69 \mathrm{~g} \mathrm{~m}^{-2}$ (SE = 9.0) in reduced precipitation. Interacting effects of clubmoss and precipitation had no influence on standing crop of forbs ( $P$ $=0.55)$, graminoids $(P=0.61)$, and total standing crop $(\mathrm{P}=0.42)$.

\section{Experiment 2}

Before irrigation on Day 0 , Leaf ${ }_{x w p}$ were similar among irrigation amounts $(P$ $=0.295)$, between clubmoss treatments $(P$ $=0.81)$, and their interacting effects $(\mathrm{P}=$ $0.92)$, averaging $-2.7 \mathrm{MPa}(\mathrm{SE}=0.03)$. Leaf $_{x w p}$ increased after irrigation, and declined over the 7-day drying period (Table 5). The decline in Leaf ${ }_{x w p}$ from days 1 to 7 was due to the interacting effects of the amount of irrigation water and days after irrigation $(\mathrm{P} \leq 0.01)$, but not by clubmoss $(P=0.06)$. Although there was a trend for higher Leaf ${ }_{\mathrm{xwp}}$ when irri- gated with at least $5 \mathrm{~mm}$ of water (Table 5 ), more than $10 \mathrm{~mm}$ of irrigation were required to impart a significant increase ( $P$ $\leq 0.05)$ in Leaf ${ }_{x w p}$ over control through time (Table 6).

\section{Discussion}

The fact that clubmoss grows in many plant communities of the Northern Mixed Prairie logically leads to the conclusion that clubmoss uses water and competes for it with other species. Whether the magnitude of the effects of clubmoss on associated species is greater than those imposed by environmental conditions, particularly the amount of precipitation, formed the basis for our studies. Van Dyne and Vogel (1967) speculated that clubmoss competes for water with most associated plants. Competition for water is possible between clubmoss and some species, but it was not significant for Junegrass and blue grama on our study in which clubmoss cover was high. In our studies, clubmoss had no significant $(P \leq 0.05)$ influence on Leaf ${ }_{x w p}$ or standing crop of plants. Therefore, the hypothesis that clubmoss reduces Leaf xwp $_{\text {p }}$ and productivity of associated plant species in the Northern Mixed Prairie is rejected. Similarly the alternative hypothesis that Leaf ${ }_{\mathrm{xwp}}$ and plant production are increased in the presence of clubmoss is not accepted. Clarke et al. (1943) also concluded that the clubmoss has minimal influence on plant communities in the Northern Mixed Prairie because of its low water requirements. Significant effects of precipitation or irrigation, and similar Leaf $_{\mathrm{xwp}}$ and plant standing crop between clubmoss treatments, indicated that the amount of precipitation received overshadowed any effects of clubmoss on Leaf $_{\mathrm{xwp}}$ and plant production. Gold and Bliss (1995) also reported that cryptogamic crusts did not affect plant water relations in arctic ecosystems.

Water availability is arguably one of the most important factors governing structure

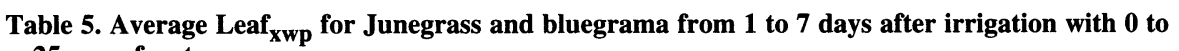
$25 \mathrm{~mm}$ of water.

\begin{tabular}{|c|c|c|c|c|c|c|c|}
\hline \multirow{2}{*}{$\begin{array}{l}\text { Days } \\
\text { after } \\
\text { irrigation }\end{array}$} & \multicolumn{6}{|c|}{ Amount of water added through irrigation (mm) } & \multirow[b]{2}{*}{25} \\
\hline & 0 & 2.5 & 5 & 10 & 15 & 20 & \\
\hline & \multicolumn{7}{|c|}{ 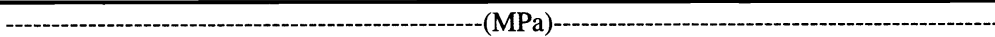 } \\
\hline 1 & -2.6 & -2.1 & -1.9 & -1.6 & -1.5 & -1.6 & -1.5 \\
\hline 2 & -2.4 & -2.2 & -1.9 & -1.7 & -1.6 & -1.4 & -1.5 \\
\hline 4 & -2.5 & -2.5 & -2.3 & -2.0 & -1.8 & -1.7 & -1.8 \\
\hline 7 & -2.4 & -2.3 & -2.3 & -1.9 & -2.0 & -1.8 & -1.9 \\
\hline \multicolumn{7}{|c|}{ Standard error (Irrigation x Days) } & 0.08 \\
\hline
\end{tabular}

and function of the Northern Mixed Prairie (Redmann 1976, Sims and Singh 1978, Smoliak 1986, Willms and Jefferson 1993). Increased precipitation in the Northern Mixed Prairie enhances plant production (Branson 1956, Cosper and Each species or group of species responds to precipitation in unique ways (Klages and Ryerson 1965, Olson et al. 1985). Response of vegetation to precipitation may also be tempered by nutrient cycling, timing and amount of precipitation, range condition, vigor of plants, range site characteristics, stage of growth, genetic limitations of the vegetation, past management, and landscape position (Weaver and Albertson 1944, Smoliak 1956, 1986 , Perry 1976, Bork et al. 2001).

Most precipitation events in the Northern Mixed Prairie of Canada are small (Table 1). We predicted that clubmoss would have it greatest effects on Leaf $_{x w p}$ when irrigated with small amounts of water because losses to interception by clubmoss were expected to be greatest for small precipitation events (Couturier and Ripley 1973). However, clubmoss had no effect on Leaf ${ }_{\text {xwp }}$ over the range of 0 to $25 \mathrm{~mm}$ of irrigation. We therefore conclude that clubmoss has negligible impacts on the water balance of a site across a range of precipitation events.

More than $10 \mathrm{~mm}$ of precipitation were required before Leaf fwp $_{\mathrm{xw}}$ increased in Junegrass and blue grama. This response contrasts with the results of Sala and Lauenroth's (1982) study in which Leaf $_{\mathrm{xwp}}$ and stomatal conductance of blue grama increased after a $5 \mathrm{~mm}$ precipitation event. However, Coupland (1950) concluded that precipitation amounts of about $7 \mathrm{~mm}$ or less have minimal influence on soil water and production in the Mixed Prairie of Canada. Physical and chemical properties of soil, canopy and litter characteristics (Naeth et al. 1991a), and antecedent precipitation events alter the effectiveness of different sized precipitation events. Differences in rooting patterns of plants among sites may also influence Thomas 1961, Klages and Ryerson 1965). 
Table 6. Probabilities that Leaf ${ }_{\mathrm{xwp}}$ are different through time between control and 6 amounts of irrigation on plots. Leaf ${ }_{x w p}$ were determined for Junegrass and blue grama.

\begin{tabular}{lccccc}
\hline \hline \multicolumn{6}{c}{ Irrigation treatment comparison } \\
\hline $\begin{array}{l}0 \text { vs. } 2.5 \\
\mathrm{~mm}\end{array}$ & $\begin{array}{c}0 \text { vs. 5 } \\
\mathrm{mm}\end{array}$ & $\begin{array}{c}0 \text { vs. 10 } \\
\mathrm{mm}\end{array}$ & $\begin{array}{c}0 \text { vs. 15 } \\
\mathrm{mm}\end{array}$ & $\begin{array}{c}0 \text { vs. 20 } \\
\mathrm{mm}\end{array}$ & $\begin{array}{c}0 \text { vs. 25 } \\
\mathrm{mm}\end{array}$ \\
\hline 0.21 & -0.07 & 0.16 & 0.03 & 0.04 & 0.02 \\
\hline
\end{tabular}

plant responses to precipitation. Although Junegrass and blue grama did not respond $(\mathrm{P} \leq 0.05)$ to precipitation events $<10 \mathrm{~mm}$, small precipitation events may be important to ecosystem functions. In fact, photosynthesis and other physiological activities in clubmoss increase quickly after precipitation (Webster and Steeves 1964, Eickmeier 1979, 1983, Harten and Eickmeier 1987). Similarly rainfall events $<4 \mathrm{~mm}$ can benefit cryptogams (Noy-Meir 1973), and microbial respiration and nutrient cycling may be stimulated by small rainfall events (De Jong et al. 1974).

Despite the absence of research on the ecological roles of clubmoss, improved plant water relations and increased plant production by eliminating or reducing clubmoss have been the primary reasons for mechanically disturbing rangeland on which this species is abundant (Dolan 1966, Wagner 1966, Taylor 1967, Ryerson et al. 1970). Many of the beliefs about the influence of clubmoss on soil and plant water relations were derived from assumptions about its effects on various aspects of the hydrologic cycle. Improved soil water and production after mechanical disturbances of rangelands that support high populations of clubmoss are likely due to changes in the chemical and physical properties of soils, micro-relief of the soil surface (Ryerson et al. 1970), and increased amounts of litter (Dolan 1966, Dolan and Taylor 1972) rather than clubmoss per se. Furthermore, precipitation is more important in determining plant productivity than mechanical disturbance in rangelands on the Northern Great Plains (Haferkamp et al. 1993). Mechanical disturbances to decrease the cover of clubmoss may be unnecessary and counterproductive to conservation of rangeland resources, and may not be economically feasible (Kulshrehtha et al. 2002).

Modifying grazing practices to improve water relations may be an alternative to mechanical disturbance on rangeland. Grazing intensity significantly affects water relations in prairie ecosystems (Johnston 1962, Naeth et al. 1991b). Other grazing management practices that maintain or increase natural litter and mulch cover may also improve water relations on a site. Litter and mulch play important roles in the dynamics of soil water on the Northern Mixed Prairie (Rauzi 1960, Willms et al. 1986,1993) by reducing incident solar radiation on the soil surface (Willms et al. 1986), which reduces soil temperatures and evaporation (Weaver and Rowland 1952, Hopkins 1954) and increases herbage yields (Willms et al. 1986, 1993, 2002). Most precipitation events in the Northern Mixed Prairie are small, and any improvement in water-use efficiency should improve the water balance of a site. In summary, range managers in the water-limited Northern Mixed Prairie may want to identify and implement grazing management practices that improve water relations before considering mechanical modification of rangeland to reduce clubmoss.

\section{Literature Cited}

Abouguendia, Z.M. 1990. A practical guide to planning for management and improvement of Saskatchewan rangeland: Range plan development. New Pasture and Grazing Tech. Proj. Regina, Sask. 2001. Herbage response to precipitation in central Alberta Boreal grasslands. J. Range Manage. 54:243-248.

Branson, F.A. 1956. Range forage production changes on a water spreader in southeastern Montana. J. Range Manage. 9:187-191.

Campbell, J.B., R.W. Lodge, A. Johnston, and S. Smoliak. 1962. Range management of grasslands and adjacent parklands in the Prairie Provinces. Canada Dept. Agr. Pub. 1133. Ottawa, Ont.

Christiansen, E.A. 1979. The Wisconsin deglaciation of southern Saskatchewan and adjacent areas. Can. J. Earth Sci. 16:913-938.

Clarke, S.E., E.W. Tisdale, and N.A. Skoglund. 1943. The effects of climate and grazing practices on shortgrass prairie vegetation in southern Alberta and southwestern Saskatchewan. Canada Dept. Agr. Tech. Bull. 46. Ottawa, Ont.

Colberg, T.J. 2000. The impact of clubmoss (Selaginella densa $\mathrm{Rydb}$.) on water relations, productivity, and plant community characteristics in Northern Mixed Prairie. M.S. Thesis, Univ. Saskatchewan, Saskatoon, Sask.
Bork, E.W., T. Thomas, and B. McDougall.
Cosper, H.R. and J.R. Thomas. 1961. Influence of supplemental run-off water and fertilizer on production and chemical composition of native forage. J. Range Manage. 14:292-297.

Coupland, R.T. 1950. Ecology of mixed prairie in Canada. Ecol. Monogr. 20:271-315.

Coupland, R.T. and R.E. Johnson. 1964. Rooting of Saskatchewan grassland species. J. Ecol. 53:475-507.

Couturier, D.E. and E.A. Ripley. 1973. Rainfall interception in mixed grass prairie. Can. J. Plant Sci. 53:659-663.

Daubenmire, R. 1959. A canopy-coverage method of vegetational analysis. Northwest Sci. 33:43-64.

DeJong, E., H.J.V. Schappert, and K.B. MacDonald. 1974. Carbon dioxide evolution from virgin and cultivated soil as affected by management practices and climate. Can. J. Soil Sci. 54:299-307.

Dolan, J.J. 1966. Long-term responses of dense clubmoss (Selaginella densa Rydb.) to range renovation practices in northern Montana. M.S. Thesis, Montana State Univ., Bozeman, Mont.

Dolan, J.J. and J.E. Taylor. 1972. Residual effects of range renovation on dense clubmoss and associated vegetation. J. Range Manage. 25:32-37.

Eickmeier, W.G. 1979. Photosynthetic recovery in the resurrection plant Selaginella lepidophylla after wetting. Oecologia 39:93-106.

Eickmeier, W.G. 1983. Photosynthetic recovery of the resurrection plant Selaginella lepidophylla (Hook. And Grev.) Spring: Effects of prior desiccation rate and mechanisms of desiccation damage. Oecologia 58:115-120.

Ellis, J.G., D.F. Acton, and H.C. Moss. 1970. The soils of the Rosetown map area (720), Saskatchewan, Univ. Saskatchewan, Saskatchewan Inst. Pedol. Pub. 202. Saskatoon, Sask.

Environment Canada, Atmospheric Environmental Service. 1982. Canada climate normals (1951-1980), temperature and precipitation (Prairie Provinces). Environ. Canada, Ottawa, Ont.

Gold, W.G. and L.C. Bliss. 1995. Water limitations and plant community development in a polar desert. Ecol. 76:1558-1568.

Haferkamp, M.R., J.D. Volesky, M.M. Borman, R.K. Heitschmidt, and P.O. Currie. 1993. Effects of mechanical treatments and climatic factors on the productivity of Northern Great Plains rangelands. J. Range Manage. 46:346-350.

Harten, J.B. and W.G. Eickmeier. 1987. Comparative desiccation tolerance of three desert pteridophytes: Response to long-term desiccation. Amer. Midl. Nat. 118:337-347.

Heady, H.F. 1952. Reseeding, fertilizing, and renovating in an ungrazed mixed prairie. J. Range Manage. 5:144-149.

Hopkins, H.H. 1954. Effects of mulch upon certain factors of the grassland environment. J. Range Manage. 7:255-258.

Hulett, G.K., R.T. Coupland, and R.L. Dix. 1966. The vegetation of dune sand areas 
within the grassland region of Saskatchewan. Can. J. Bot. 44:1307-1330.

Johnston, A. 1962. Effects of grazing intensity and cover on the water-intake rate of fescue grassland. J. Range Manage. 15:79-82.

Klages, M.G. and D.E. Ryerson. 1965. Effect of nitrogen and irrigation on yield and botanical composition of western Montana range. Agron. J. 57:78-81.

Kulshreshtha, S.N., J.T. Romo, and Peng Hongjia. 2002. Economic analysis of mechanically disturbing rangeland to reduce clubmoss in Saskatchewan. Can. J. Plant Sci. 82:739-746.

Majorowicz, A.K. 1963. Clubmoss infestation on northeastern Montana rangeland. Abstr. Annu. Meeting. Amer. Soc. Range Manage. 16:72.

Naeth, M.A., A.W. Bailey, D.S. Chanasyk, and D.J. Pluth. 1991a. Water holding capacity of litter and soil organic matter in mixed prairie and fescue grassland ecosystems of Alberta. J. Range Manage. 44:13-17.

Naeth, M.A., D.S. Chanasyk, R.L. Rothwell, and A.W. Bailey, 1991b. Grazing impacts on soil water in mixed Prairie and fescue grassland ecosystems of Alberta. Can. J. Soil Sci. 71:313-325.

Noy-Meir, I. 1973. Desert ecosystems: Environment and producers. Annu. Rev. Ecol. Syst. 4:25-51.

Olson, K.C., R.S. White, and B.W. Sindelar. 1985. Response of vegetation of the Northern Great Plains to precipitation amount and grazing intensity. J. Range Manage. 38:357-361.

Perry, D.A. 1976. The effects of weather modification on Northern Great Plains grasslands: A preliminary assessment. J. Range Manage. 29:272-278.

Petersen, R.G. 1985. Design and analysis of experiments. Marcel-Decker Inc., New York, N.Y.
Rauzi, F. 1960. Water-intake studies on range soils at three locations in the Northern Plains. J. Range Manage. 13:179-184.

Redmann, R.E. 1976. Plant-water relationships in a mixed grassland. Oecologia 23:283-295.

Ritchie, G.A. and T.M. Hinckley. 1975. The pressure chamber as an instrument for ecological research. Advan. Ecol. Res. 9:165-254.

Ryerson, D.E., J.E. Taylor, L.O. Baker, H.A.R. Houlton, and D.W. Stroud. 1970. Clubmoss on Montana rangelands: Distribution-control-range relationships. Montana Agr. Exp. Sta. Bull. 645. Montana State Univ. Bozeman, Mont.

Sala, O.E. and W.K. Lauenroth. 1982. Small rainfall events: An ecological role in semiarid regions. Oecologia 53:301-304.

Shay, J.M., M. Herring, and B.S. Dyck. 2000. Dune colonization in the Bald Hills, Southwestern Manitoba. Can. Field-Natur. 114:612-627.

Sims, P.L. and J.S. Singh. 1978. II. The structure and function of ten western North American grasslands. J. Ecol. 66:547-572.

Smoliak, S. 1956. Influence of climatic conditions on forage production of shortgrass rangeland. J. Range Manage. 9:89-91.

Smoliak, S. 1965. Effects of manure, straw and inorganic fertilizers on Northern Great Plains ranges. J. Range Manage. 18:11-15.

Smoliak, S. 1986. Influence of climatic conditions on production of Stipa-Bouteloua prairie over a 50-year period. J. Range Manage. 39:100-103.

Smoliak, S., J.F. Dormaar, and A. Johnston. 1972. Long-term grazing effects on StipaBouteloua prairie soils. J. Range Manage. 25:246-250.
Steel, R.G.D. and J.H. Torrie. 1980. Principles and procedures of statistics. A biometric approach. $2^{\text {nd }}$ ed. McGraw-Hill Book Co., Toronto, Ont.

Taylor, J.E. 1967. Range pitting and nitrogen fertilization on mixed prairie rangeland in northern Montana. M.S. Thesis, Montana State Univ., Bozeman, Mont.

Van Dyne, G.M. and W.G. Vogel. 1967. Relation of Selaginella densa to site, grazing, and climate. Ecol. 48:438-444.

Wagner, S.F. 1966. Selaginella densa Rybd. and its chemical control. M.S. Thesis, Montana State Univ., Bozeman, Mont.

Weaver, J.E. and F.W. Albertson. 1944. Nature and degree of recovery of grassland from the great drought of 1933 to 1940 . Ecol. Monogr. 14:393-479.

Weaver, J.E. and N.W. Rowland. 1952. Effects of excessive natural mulch on development, yield, and structure of native grassland. Bot. Gaz. 114:1-19.

Webster, T.R. and T.A. Steeves. 1964. Observations on drought resistance of Selaginella densa Rydb. Amer. Fern J. 54:189-196.

Willms, W.D. and P.G. Jefferson. 1993. Production characteristics of the mixed prairie: Constraints and potential. Can. J. Anim. Sci. 73:765-778.

Willms, W.D., S.M. McGinn, and J.F. Dormaar. 1993. Influence of litter on herbage production in the Mixed Prairie. J. Range Manage. 46:320-324.

Willms, W.D., S. Smoliak, and A.W. Bailey. 1986. Herbage production following litter removal on Alberta native grasslands. J. Range Manage. 39:536-540.

Willms, W.D. J.F. Dormaar, B.W. Adams, and H.E. Douwes. 2002. Response of mixed prairie to protection from grazing. J. Range Manage. 55:210-216. 